E3S Web of Conferences 1, 35005 (2013)

DOI: $10.1051 / \mathrm{e} 3$ sconf $/ 20130135005$

(C) Owned by the authors, published by EDP Sciences, 2013

\title{
Preliminary report on arsenic and heavy metals contents in soils and stream bed sediments of Cornia, Bruna and Alma coastal plains (Southern Tuscany)
}

\author{
F. Dughetti ${ }^{1}$ and G. Tanelli ${ }^{2}$ \\ ${ }^{1}$ Department of Earth Science, University of Florence, Via La Pira 4, Firenze, ITALY, francesca.dughetti@unifi.it \\ ${ }^{2}$ Department of Earth Science, University of Florence, Via La Pira 4, Firenze, ITALY, giuseppe.tanelli@unifi.it
}

\begin{abstract}
The Department of Earth Sciences of University of Florence has conducted over the past ten years, numerous studies about the distribution of arsenic and heavy metals in mineralized areas of Tuscany, particularly in the Pecora basin. The area hosts several polymetallic ore bodies and a pyrite ore deposit. The studies have identified several geochemical anomalies $(\mathrm{As}, \mathrm{Cu}, \mathrm{Pb}, \mathrm{Zn} . .$.$) both in the areas which host the ore$ bodies and in the coastal plain (Scarlino Plain). To increase the knowledge concerning the distribution of As and heavy metals in other Tuscan coastal plains, research is under way in the alluvial plains of the Bruna, Cornia and Alma rivers. The preliminary analysis have focused on soils and stream sediments, to better understand the correlations between the downstream transport of rivers and the soils. We have made physic-chemical analysis, particle size analysis, mineralogical analysis for X-ray powder diffraction, chemical analysis for the determination of major element (X-ray Fluorescence) and for the determination of 35 minor elements and traces (AAS and ICP).Preliminary data show high concentrations of several elements (As, Zn, Co...). The concentrations of these elements in soils and stream bed sediments are not always consistent; in particular we have found higher concentrations in soils than in stream bed sediments in Cornia Plain, while the opposite happens in the Bruna basin. Therefore the natural processes of rocks weathering does not seem to have affected uniformly. The distribution of As and heavy metals in soils and stream bed sediments of the all three basins of interest are still under investigation.
\end{abstract}

Key words: Heavy metals, coastal plains, Southern Tuscany, soils.

\section{Introduction}

Southern Tuscany hosts a number of ore deposits which have been actively exploited since the Etruscan period until very recent time. Natural processes of rocks weathering led to the dispersion in the environment of toxic elements.

The Department of Earth Sciences of University of Florence has conducted over the past ten years, numerous studies about the distribution of arsenic and heavy metals in mineralized areas of Tuscany, particularly in the Pecora basin.

The Pecora river drainage-basin is located in the SW part of Colline Metallifere. The area hosts several polymetallic ore bodies and a pyrite ore deposit. The studies have identified several geochemical anomalies $(\mathrm{As}, \mathrm{Cu}, \mathrm{Pb}, \mathrm{Zn} . .$.$) both in the areas which host the ore$ bodies and in the coastal plain (Scarlino Plain).

The studies suggest that in Scarlino Plain the primary geogenic geochemical anomalies have been overprinted by an anthropogenic input.

To increase the knowledge concerning the distribution of As and heavy metals in other Tuscan coastal plains, research is under way in the alluvial plains of the Bruna, Cornia and Alma rivers.

The Bruna Valley is the catchment area adjacent to the Pecora Valley, bordered on the S-SE with the latter through a watershed that divides them. The two areas, based on paleo-reconstructions hydrographic studies, show a relatively recent common history.

The Cornia Valley is the catchment area bordered on the N-NO by the Pecora basin. This basin hosts several polymetallic ore bodies and high-enthalpy geothermal fields, located around the area of Sasso Pisano.

Finally, the Alma basin is bordered on the north by the Pecora basin and on the south by the Bruna basin. This small size basin has lithologies common with neighboring basins, but not directly affected by mineralizations. The "Pian d'Alma" coastal plain may 
represent the geochemical baseline of the Southern Tuscany.

\section{Materials and Methods}

The preliminary analysis have focused on soils and stream sediments, to better understand the correlations between the downstream transport of rivers and the soils. The soil represents together with water (even from a legal point of view) the matrix of most interest to the risk of human exposure to contamination by heavy metals and toxic elements.

Sampling sites were chosen on the basis of the distribution of different types of soils as reported in the map of Regione Toscana. The soils are subdivided on the basis of the origin of sediments, related to different areas (recent channel, alluvial fan or lagoon). Surface (0-10 $\mathrm{cm})$ and subsurface $(40-80 \mathrm{~cm})$ soil samples were collected from each site. Deep horizons were therefore sampled in order to characterize, if possible, the natural local pedo-geochemical background (Baize and Sterckeman, 2001).

Sediment samples are collected along the courses of the Cornia, Alma and Bruna rivers.

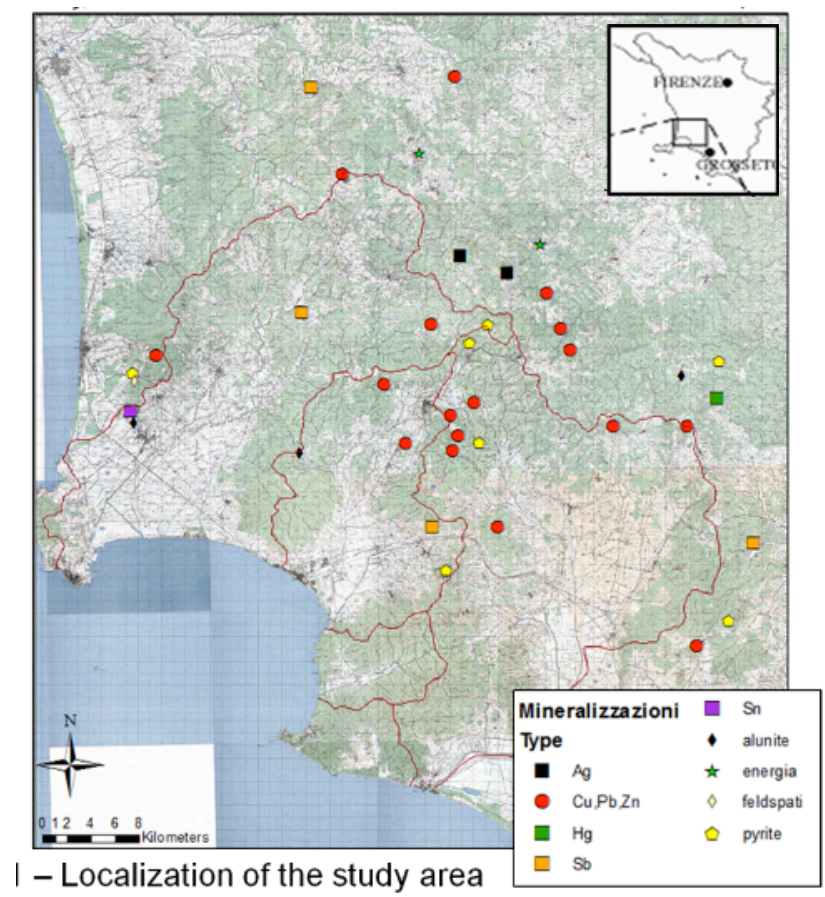

The samples were air-dried at room temperature, disaggregated with an agate mortar, and then sieved. The fraction of sediment smaller than $150 \mu \mathrm{m}$ and the fraction of soil smaller than $2 \mathrm{~mm}$ were used for chemical and mineralogical analysis. Quantitative chemical analysis of major elements were performed by X-ray Fluorescence and analysis of 35 minor elements and traces were performed by AAS and ICP-OES. Mineralogical analysis were performed by X-ray powder diffraction (XRD).

Granulometric curves of soil samples were constructed using conventional wet hand sieving and using decantation method for fine grain size.

\section{Results and Discussion}

Chemical data indicate that the $<2 \mathrm{~mm}$ soils (consisting of 23 samples of topsoil and 20 subsoil samples) collected in the three coastal plains, consists of a dominant alumo-silicate fraction $(55-85 \%)$. The carbonate fraction $(0.4-8 \%)$ and organic content $(5-20 \%)$ are significant in few samples.

The stream bed sediments present a composition primarily allumo-silicate $(55-78 \%)$ with variable contents of $\mathrm{Fe}\left(\mathrm{Fe}_{\mathrm{TO}} 0.3-12 \%\right)$ and organic fraction $(8-18 \%)$, in agreement with the composition of the rocks that crop out in the basins (Tuscan Series formations and claylimestone formations of the Ligurian Units).

Mineralogical analysis made for X-ray powder diffraction, show high content of quartz and feldspar, followed by calcite and Fe oxy-hydroxides and sulfides in traces.

The preliminary results show high concentrations of As $(21-57 \mathrm{mg} / \mathrm{kg})$ in the coastal plain of Piombino (Cornia basin). These values exceed the law limit of 20 $\mathrm{mg} / \mathrm{kg}$ for Private and Public Land Use and several samples are also over the law limit of $50 \mathrm{mg} / \mathrm{kg}$ for Commercial and Industrial Land Use (D. Lgs. 152/06). The samples which present high concentration of As, also have contents in Co over the law limit of $20 \mathrm{mg} / \mathrm{kg}$. Also in the coastal plain of Castiglione della Pescaia (Bruna basin), there are several samples which have concentrations of As $(7-29 \mathrm{mg} / \mathrm{kg}), \mathrm{Zn}(31-163 \mathrm{mg} / \mathrm{kg})$ and of $\mathrm{Co}(8-36 \mathrm{mg} / \mathrm{kg})$ that are over the law limits $(20$ $\mathrm{mg} / \mathrm{kg}, 150 \mathrm{mg} / \mathrm{kg}$ and $20 \mathrm{mg} / \mathrm{kg}$ respectively-Private and Public Land Use.

Instead, the soils sampled in Pian d'Alma present concentrations below the law limits, and consistent with the values of Tuscan background (Benvegnù et al. 1993) (Fig. 2).

It is interesting to note that the values of heavy metals and arsenic are not distributed in connection with the type of soil, even if the different land use could affect the distribution of toxic elements. Zinc concentrations in all investigated plains are higher in topsoil than subsoil samples. Whereas the concentrations of copper, lead and arsenic do not show significant difference between topsoil and subsoil. In Cornia Plain, the subsoil samples are more enriched in As than topsoil.

The distribution of $\mathrm{As}, \mathrm{Cu}, \mathrm{Pb}$ and $\mathrm{Zn}$ along the Bruna river is characterized by lower values in the lower stretch towards the plain and higher values in the upper stretch near the mining district. This findings was not surprising considering the presence of intensive mining activity and the natural weathering of the mine deposits and waste stocks. Along the Cornia river the concentrations of $\mathrm{As}, \mathrm{Cu}, \mathrm{Zn}$ and $\mathrm{Pb}$ are not well correlated and it's not possible to note a particular distribution of these elements from the source to the river outlet. Several unexpected hot spots were found in the plain. These point anomalies were unpredictable merely on geological and geochemical bases.

Along the Alma river all the samples show lower values (Fig. 3). 

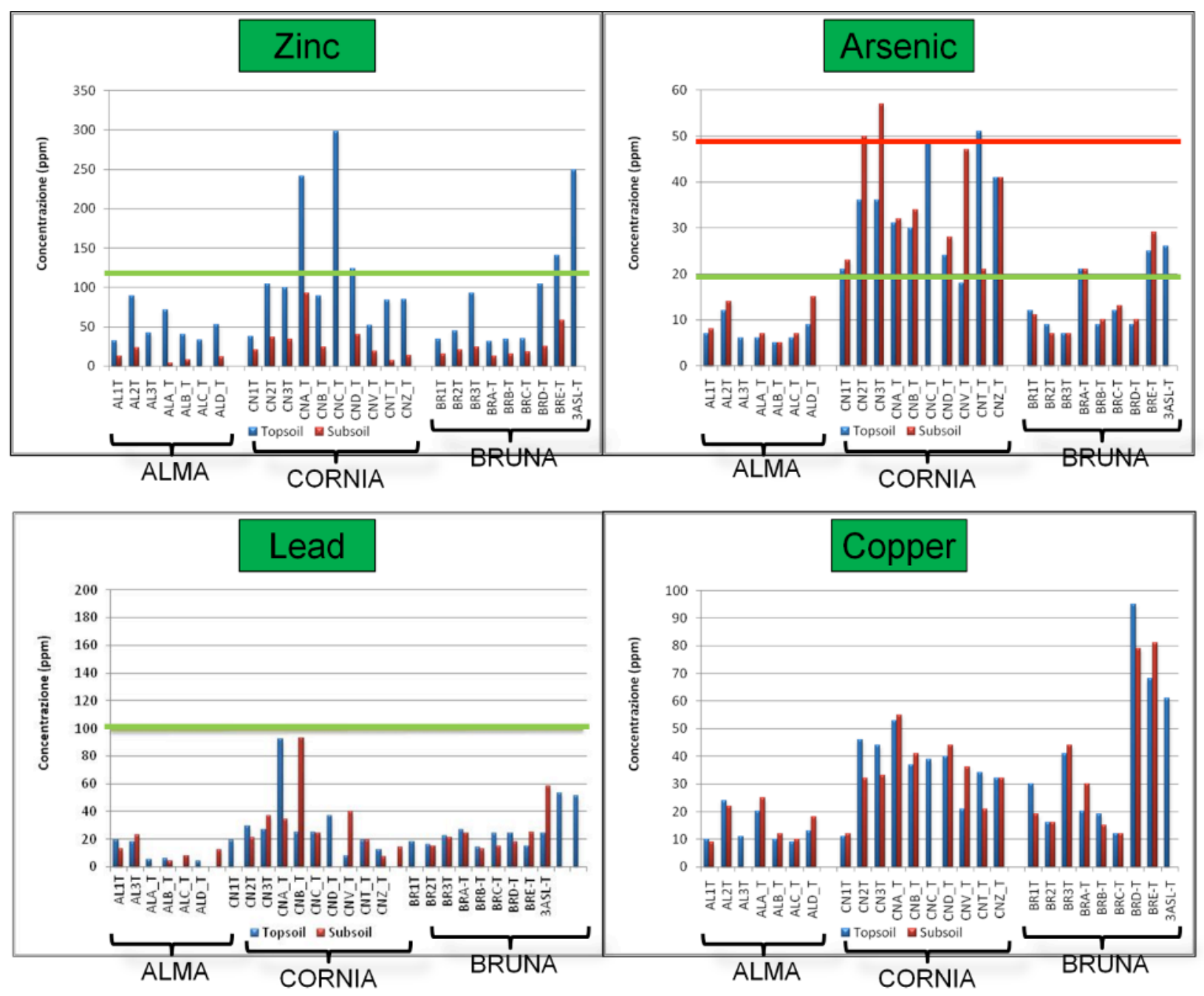

Fig. 2. Diagrams show the Zinc, Arsenic, Lead and Copper concentrations. Green line indicate the law limit for Private and Public Land Use; red line indicate the law limit for Industrial Land Use (D. Lgs. 152/06).
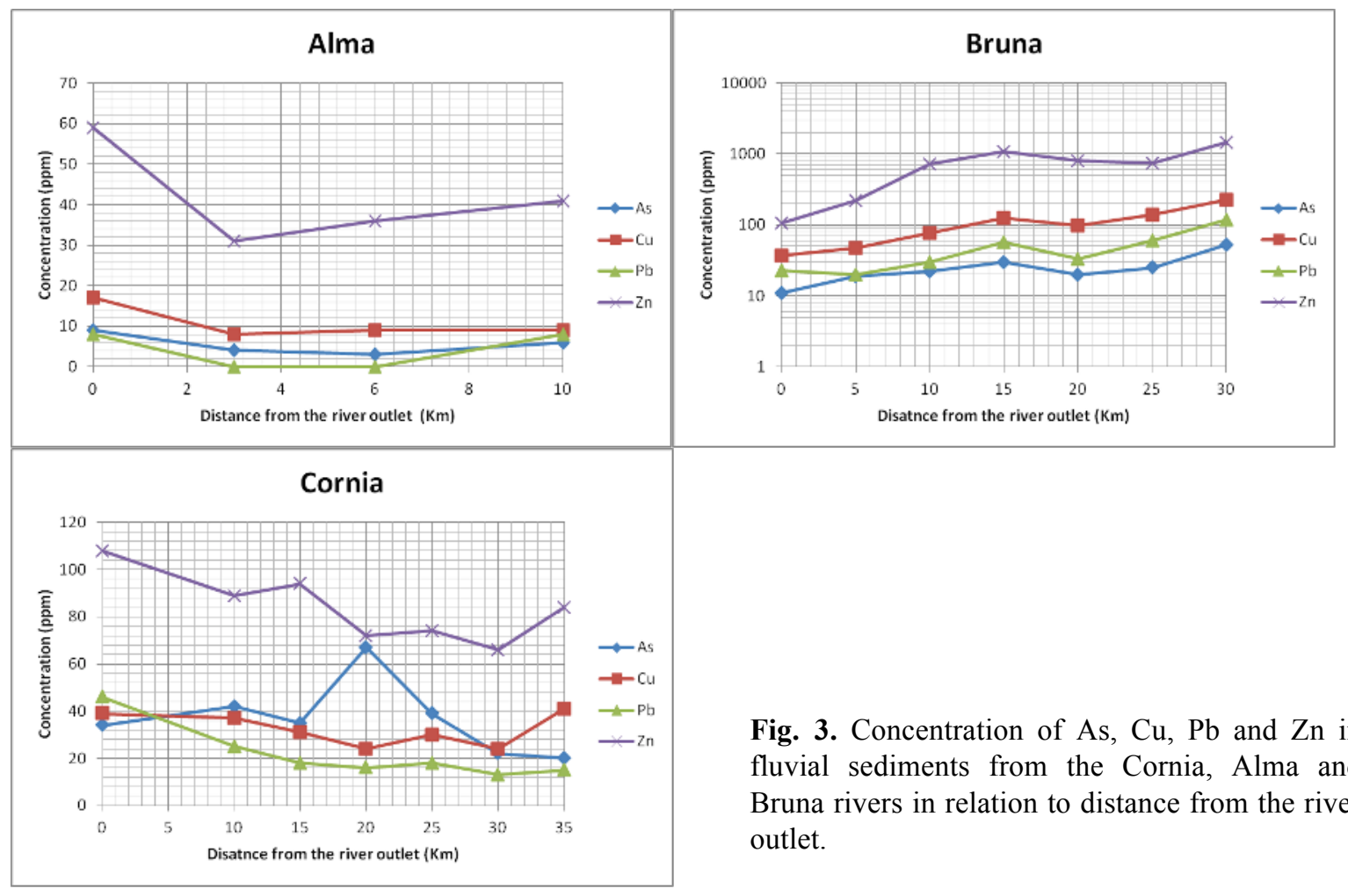

Fig. 3. Concentration of $\mathrm{As}, \mathrm{Cu}, \mathrm{Pb}$ and $\mathrm{Zn}$ in fluvial sediments from the Cornia, Alma and Bruna rivers in relation to distance from the river outlet. 
Soils and stream bed sediments of the all three basins are still under investigation, but some preliminary consideration are possible. Chemical data indicate that in the Cornia coastal plain the soils show high concentrations in $\mathrm{As}, \mathrm{Cu}, \mathrm{Pb}$ and $\mathrm{Zn}$. In the Bruna coastal plain the soils are not particularly enriched. It will be interesting to understand the correlation between the soil values and the stream bed sediments values, to conjecture the possible source of these elements in Cornia and Bruna plains. In this context the Alma basin should be represent a "background basin".

\section{Acknowledgements}

The authors thank the financial supports providing from PRIN 2006 (Research Program of national Interest. Research Unit: G. Tanelli) and the scientific program between the Department of Earth Science of the University of Florence, ARPAT and Regione Toscana.

\section{References}

Baize D. \& Sterckeman T. (2001) - Of the necessity of knowledge of the natural pedo-geochemical background content in the evaluation of the contamination of soils by trace elements - The Science of Total Environment 264, 127-139.

Benvegnù E., Brondi A., Colica A., Conti P., Guasparri G., Polizzano C., Sabatini G., Tassoni E. (1993): Studies of migration factors in clay in real situation; study of fractures in clays of the neogenic basin of Siena - Nuclear Sc. and Tech., Commission of European Communities Report. pp.1-53.

Costagliola P., Benvenuti M.M., Benvenuti M.G., Di Benedetto F., Lattanzi P. (2010) - Quaternary sediment geochemistry as a proxy for toxic element source: A case study of arsenic in the Pecora Valley (Southern Tuscany, Italy) - Chemical Geology 270, 80-89.

Rossato L., Dughetti F., Fontani F., Paolieri M., Tanelli G. (2011) - Arsenic and polymetallic anomalies in the Neogene-Quaternary sequence of La Botte borehole in the Scarlino Plain (Grosseto) - Southern Tuscany - Italy. Neues Jahrbuch für Mineralogie, 188/1, 87-98. 